\title{
Revista
}

de Estudios

\section{de la Administración}

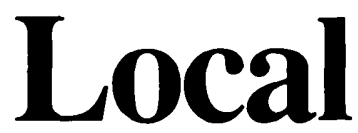

y Autonómica

\section{4}

OCTUBRE-DICIEMBRE 1994

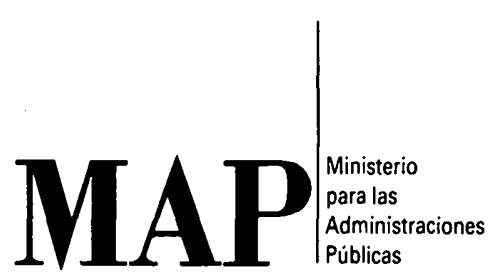

INAP Instituto Nacional de Administración Pública 
REALA-1994, núm. 264. PRIMERAS

REALA-1994, núm. 264. PRIMERAS 